\title{
Gender and Urbanization in Nigeria
}

\author{
Denen, Grace Mbaveren \\ Asaju, Kenang \\ Bott, Hajara \\ Department of Sociology,Plateau State University, Bokkos-Nigeria
}

\section{Doi:10.5901/mjss.2014.v5n26p33}

\begin{abstract}
In Nigeria, like other parts of the world, urbanization means different things for men and women. This paper has identified the transfer of traditional patriarchal tendencies and attitudes towards women to the urban centers, resulting to the unchanging low status of women in the cities. Practical recommendations are made for urban policy makers, urban developers, development organizations and the general public to change the way women are seen as underdogs; in order to improve the lives of all urban citizens. Opinions of women groups and in-depth secondary data analysis formed the basis for this conclusion.
\end{abstract}

\section{Introduction}

Feminist perspectives have only recently been incorporated in urban studies. From this perspective, urbanization reflects the workings not only of the political economy but also of patriarchy. Cities in different parts of the world have prevailing ideologies of how women and men should think, feel and act; how access to social positions and control of resources should be manage and how relationships between men and women should be conducted.

According to Kendall (2008:648), two types of patriarchy exist in central cities like New York, Lagos, Abuja, and Johannesburg-private and public patriarchies. Due to their higher density and great diversity, serve as a paradoxical challenge to private patriarchy found in the home and work places in lower-density, homogenous areas such as suburbs and rural areas, private patriarchy is based on strongly gendered division of labour in the home, gender-segregated paid employment and women's dependence on men's income. At the same time, cities may foster public patriarchy in the form of women's increasing independence from parents and men and dependence on paid work and the state for income as well as their decreasing emotional inter-dependence with men.

Public patriarchy may be perpetuated by citizens through policies that limit women's access to paid work, social/public utilities. However, such cities may also be a forum for challenging patriarchy; all residents who differ in material status, paternity, sexual orientation-as is the case now in many west African cities; where city people have joined their voices against same sex marriage; class, ethnicity tend to live close to one another and may have a common belief that both public and private patriarchy should be eliminated (Kendall 2008, IIED 2013). This paper has examined the gender effect of urbanization; the opportunities women enjoy in urban centers and the persistent inequalities they face in terms of access to decent work, assets, mobility, security, violence etc.

In discussing the gender impact of urbanization, Schaefer (2008), using the interactionist theorists' view, see men in the urban space as influenced by the "quick pace" of the city and the pervasiveness of economic relations choose to avoid emotional involvement in things taken place around them, especially as they affect women. According to Ityavyar (2002), many people feel wary with women because most gender interactions in the city are economic rather than social. Attribute such as punctuality and exactness are rewarded, but friendliness and warmth in the interpersonal relations cccccare viewed as personal weakness which often hurt women and endanger their health/lives. Some women act reserved to cloak their deeper feelings of love and or distrust towards men-"which, in itself hurts a great deal" (respondent).

Another gendered impact of urbanization is that women and men experience city life differently, some men view the city as sexual space in which women, base on their sexual desirability and accessibility, are categorize as prostitutes, temptresses' or virtuous women in need of protection by men or police officers. Some women groups however feel that the solution to women vulnerability in the city is not found in offering protection for them, but rather in changing men's and 
public perceptions that women are, and can be treated as sexual objects because of the impersonality of the city (Wilson 1991, Kendal 2008, Ityavyar 2002, Okpeh and Pam Sha 2007, Akanji 2007).

According to lliya (2007), the patriarchal system in the city is not much different from that in the rural or suburban areas. Women are still riddled with the status of second class citizen, plurality of children, depending on men for support for access to basic education, income generation, recreational activities, weigh on urban women and constitute debilitating factors for a life of dignity. Illiya (2007) frowns are the attitudinal bias in the organizations and work places that prevent women from reaching their full potentials.

Schaefer (2008), decry the "glass ceiling" that has continued to block women from occupational position or top management positions. He attributes the effects of this glass ceiling principally to the fears and prejudices of men who believe that the inclusion of women in management circles will threaten their power and feeling of superiority. Women who attempt to get to the top are often view with hostility as being too ambitious in order to achieve an identity of their own. Schaefer (2008) sees women as striving to change, without a corresponding change in the positive perception by the society of women's roles and active contribution in the process of urbanization through their paid and unpaid work.

\section{Women Health Issues in the City}

Women in the urban areas suffer health problems that are child-birth related negligence, sex related health challenges, and women without means of their own are adversely affected by communicable diseases like STDs/HIV AIDS. Their dependent relationship with men render them vulnerable and powerless to reject marriage, risky behavior or negative preventive measures, for instance unprotected sexual relation, since they look to men for provisions or some monetary assistance (Ityavyar 2002, Respondents 2014).

Urban women's suffer physical violence and murder by husbands, boyfriends, and other male acquaintances more often than their rural or suburban counterparts. Even working/upper class women often find themselves in unequaladvantaged relationships with men, which expose them to all manner of violence, indignities and death at the slightest provocation-argument, due to the anonymity of urban life. Personal drivers and other domestic servants find women employers as easy target to steal from, connive with criminals and murder to get their possessions (respondent, 2014). Buttressing their point, a respondent recall an NTA report of a police man gunning down his ex-wife, along with othersincluding the land lady in whose compound the ex-wife rented a room. For sure the story would have been different if the landlord were a man, and in a rural settings where 'every ones business is every ones'.

Another respondent revealed how her husband likes to humiliate her in front of their visitors and co-tenants, but that she bears it, knowing that, that is what makes him feel strong to provide for her and her children( interview in Jos, 2014)

According to Tacoli (2013), urbanization is a "double-edged" sword for women, it is often associated with independence and opportunities, but the women experience high risk of violence and constraints on employment, mobility and leadership that reflect deep gender-base inequalities, even though gender relations are being transform by the economy, political and social changes. Women make significant contributions in their households, neighborhoods, and the city through their paid and unpaid labour, they still face persist inequalities in terms of access to decent work, personal safety/security, financial and physical assets, as well as representation in formal structure of urban governance. Tacoli (2013) expresses her discomfortabilty in the ambivalent role of paid employment in promoting more gender relations, also the role of women in improving the infrastructure and services in low income neighborhoods and the constraint they face in securing recognition for their contributions.

In her (2012) study on "urbanization, gender and urban poverty: paid work and unpaid care work in the city", Tacoli underscored the relatedness of women mobility in the city to a variety of activities-from work place to school runs, to markets; unlike men, who often move from home to work, to relaxation centers. Women bear the burden of balancing time for paid work and domestic responsibility... at the same time they face constant harassment, physical violence, excess work load, which act as restriction on women performance, mobility and their right to urban space.

Chant (2013) strongly sees the need for people to avoid the assumptions that women are a homogenous category. Although urban women share a common identity with the rural women base on the prevailing social norms that assign them the major responsibility in reproduction and care giving, they are a heterogeneous group. Poor urban women face differences constraints from those faced by higher income women who are likely to have access to education and income that enable them for instance hire domestic help.

However, Simmel ( kendall 2008) is of the view that urban life is not completely negative; according to him, urban life also has a liberating effect on people, including women because they have opportunities of individualism and autonomy that is not found in isolated rural areas and suburban centers. 


\section{Urban Opportunities for Women}

Generally when women live home to urban centers, the immediate thought of all and sundry is "automatic good life". Urbanization affords women the opportunity to obtain paid employment that gives them both socio-economic emancipation, and a voice into some neighborhoods' discussion and decision making. They have access and often participate in operating community saving schemes which built women's leadership and upgrade the social and even physical infrastructural development of such urban communities.

- Income, education and ideology influence women's decision making in urban centers.

- Better opportunities exist in cities for women to engage in formal and non-formal paid employment often without the occupational glass ceiling.

- There is a relaxation of rigid social values and norms that defines women as sub ordinates to fathers, husbands, brothers.

- They have access to better services e.g. Healthcare, which enable them lower or promote fertility rates, etc.( IIED,2013)

Another point of diversity is that urban centers have a higher proportion of women who are heads of families/households, who have different sets of responsibilities and often with heavier work burdens, but relatively more independent. The life circle of an urban woman also makes a fundamental difference in the manner/efficiency she combines domestic chores with paid work. It also largely defines her identity in the household, each of which entails gender relations. Working women are often perceived as a lost of social status, as a failure of a male head t o provide for his home.

Urban women who work in unpaid care work, life is even more costly for them, they live in poor housing conditions, difficulty in accessing health services, schools, and unsafe neighborhoods, environmental hazards, limited access to water which place more burden for child care, food preparation, cleaning and washing, which are all women responsibilities; which put a lot of stress and strain on their time, health, emotions-amounting to all kinds of impoverishments (Ityavyar 2002).

These, according to Apenda in (Okpeh and Pam Sha eds. 2007) throw urban women into several dilemmas: workload, environmental ideas and directions about what is right and proper behaviour in a giving urban space, the conflict within them- whether they are good-women, mothers, wives; role conflict e.g. marital roles, work demands. Another dilemma women face is that, their additional income is needed to ease many issues in the home, but create other problems that impact negatively on marriage, sex, children, lifestyles etc. Due to dual responsibility of house work and office work, women wake up during week days by 4am, to cook, bath/dress children for school, drop them to school, and go to work before 8:00am. The husband might accept the work and its proceeds, but is not prepared to share in the domestic chores, or looking after children. It also sets her against in-laws who feel she enjoys freedom and higher status. For few sensible and sympathetic husbands who share in some house work to assist, get such names as 'kept man', "woman wrapper", "madam's wife" from their relatives and friends, which often discourage even the sensitive men (Respondents).

In conclusion, we take the advice of Fogarty et al (eds)(2010), "these circumstances as articulated as responsibilities of urban women calls for role redefinition and allocations of duties not merely for the women, but also for every member of the households and the entire urban public. Until this is done to lessen the work load of women, they will continue to wobble in these conflicts and everyone will be adversely affected; which will negate the level of self , family, communities and national development .

\section{Recommendations}

- Since the power of those in authority keeps women down, there is need for the power of women united to bring about positive change and create an alternative gender situation, not only in urban centers, but in all human spaces:

- There is urgent need to re-orientate the society (from family role and attitudes socialization) to accept fairness (equity), complementarities of gender roles, by continually talking about it, applying, assertiveness by women where and when an opportunity present itself.

- Women need to change in their willingness to take risks, become better educated in public issues and their roles through active participation-talk knowledgeably about politics, cars, sports, occupations, participate in seminars, workshops, conferences, women need to become less rigid, more flexible and amendable to 
positive dictates of social and occupational positions.

- There is growing need to build alliances across gender lines, embrace and advocate a more democratic approach to public matters and effective disseminations of information on public issues and areas and victories of women for others to imbibe.

- Women must unite! Eliminate the un-necessary rivalry, hostility towards fellow women, to conquer their common enemy- the society.

\section{References}

Apenda, A.Z. (2007), "Culture as a barrier to women leadership", in Okpeh,O.O.\& Sha, D.P.(eds). Gender, Power and Politics in Nigeria. Makurdi: Aboki Publishers.

Chant, S. (2013). IIED vol25 no.1:26-31.

Fogarty, Wilson, Nicola (2010). Amnesty international: "insecurty and indignity": women's experiences in the slums of Nairibi, Kenya: London: AlPs.

Ityavyar, D.(2002). Women's Health and Economic Empowerment Initiative in Nigeria. Lagos: Inter-gender monograph series.

Illiya, L (2007). Mainstreaming Gender in the Trade Unions. Abuja: NLC Report.

Ingyoroko, M. (2007)."Gender Equality and the Destruction of the mechanisms for value Inculcation in the Nigerian Child (an alternative perspective): conference proceedings of the Nigerian society for Educational Psychologists. Makurdi: UNI Agriculture.

Kendall, D. (2008). Sociology in our Times Belmont: Baylor University- Thomson.

Schaefer,R. (2008). Sociology matters. New York: Mcgraw Hill.

Tacoli, C. (2013)." Urbanization: A Double-edged sword for women". IIED Vol25 no.1:3-8.

Chant, S.(2013). IIIED VOL 25 No. 1:26-31

S.IIED Vol 25no. 1:26-31.

Fogarty, Wilson, Nicola (2010). Amnesty international: insecurity and Indignity: Women's experiences in the slums of Nairobi, Kenya; London: AIP. 